\title{
The Potential of Russian Economy and Innovative Ways of its Development
}

\author{
Maksim V. Selyukov ${ }^{1}$, Natalya P. Shalygina ${ }^{2}$, Irina A. Kodenko ${ }^{3}$, Irina M. Dobrydina ${ }^{4}$,Natalya A. Mamatova ${ }^{5}$ \\ 1, 2, 3, 5 Belgorod State University, 308015, Russia, Belgorod, Pobedy St., 85, ${ }^{4} 302020$ Orel State University \\ Russia, Orel, Naugorskoe shosse, 29 \\ *Email:selyukov@bsu.edu.ru
}

Received: 21st October 2017 Accepted: 16th November 2017, Published: 31st December 2017

\begin{abstract}
In the article the authors analyzed the trends of Russia's integration into the world economy, explored the factors of influence that determine the position of the Russian Federation in the global economy, and considered the features of the development of foreign economic activity of Russia and its regions. Issues concerning regulation of foreign economic activity play a special role in the state's economy, matter how competently and efficiently it is implemented, taking into account modern trends of development of international trade depends on a country's integration into the world economy. In modern conditions of global competition, the further involvement of the Russian Federation as a full member of the international economic relations, preservation of positions in international economic and trade space, it is determined by the effectiveness of foreign economic policy, the success of which determines the actual state of the national economy.
\end{abstract}

Keywords: World Economy, Foreign Policy, Innovation Policy, Foreign Economic Activity, Innovative Activity, Trade and Economic Relations, Social-Economic Development.

\section{Introduction}

The modern stage of interaction of subjects of world economy is characterized by the expansion of the range of factors influencing their trade and economic relations, investment exchange, production and technology relationship, the factors, internal and external; operating at the national, regional, sub regional, and global levels.

The complexity of the interconnections between national and global processes of development, between economic and political interests of the countries and their associations appeared in the middle of the second decade of the XXI century in a sharp change in the conditions of development of foreign economic relations of Russia. The process of globalization is irreversible, but the movement for openness of the national social-economic systems may not be uniform, and empowering their participation in the world economic exchange is straightforward.

At present, many developed countries, to influence the foreign policy and the global economy, using different economic instruments. Economic instruments of foreign policy at the present stage include international trade and economic sanctions, the establishment of regional trade and economic blocks and regimes, management of international financial flows, the use of external debt, foreign direct investment, the provision of economic and humanitarian aid, and the manipulation of the activities of international financial institutions.

\section{Materials and Methods}

After studying work of authors presented above, it can be concluded that in the light of changes in geopolitical and geo-economic realities of the possibility of strengthening international position of Russia in the medium term are limited to stringent internal and external financial and economic conditions. The strategic interests of the country require new approaches to the selection of areas and partners in the framework of cooperation on attracting and developing new technologies; to enhance the capacity building of production and technological capacity and increase the production of products with high added value; to analyze the potential impact of long-term factors such as the acceleration of the global spread of innovation, strengthening the role of the financial component of the interaction in the world economy.

Economic modernization and its innovative development is one of priority directions of the state policy of Russia. Its implementation is reflected in the strategy of innovative development of the Russian Federation for the period up to 2020 and in the state program "Economic development and innovative economy" for the elaboration of regional programs of innovative development.

The purpose of this article is to determine directions of Russia's integration into the world economy and the possibility of participation of Russia and its regional entities in the global innovation system.

The current world situation is actualized issues of long-term strengthening of the positions of the Russian Federation on the world markets, the decision of problems of international security, including financial, energy, information, food, environment; the participation of Russia in the development of measures to improve international standards for financial regulation and strengthening international cooperation.

To evaluate the relation of positions of national social-economic systems, the prospects for their role in the world community the authors examined a wide range of indicators that characterize the economic development, finance, scientific and technological 
potential, human resources; trade, investment and other exchanges.

One of the key (and most used) national development indicators - GDP - Russia occupies the 6th place in the world. At the beginning of the XXI century have tended to strengthen the positions of many countries on this indicator, especially China, and the substantial separation the USA and China from other countries (Table. 1).

In 2015, Russia was in the top ten leading countries on commodity exports (percentage of exports of goods $-2.8 \%$ ) and in the top twenty - for services exports (share of exports of services $-1.4 \%$ ). For comparison, according to the World Trade Organization, China's share in exports of goods was
$11.7 \%$, the share of exports of services $-4.4 \%$ (World trade report, 2015).

However, Russia was integrated into the world economy mainly due to the export of raw materials, and financial stability of the Russian economy is largely under the influence of fluctuations in the prices and demand for natural resources. According to the Ministry of Economic Development, the share of energy in Russian exports exceeds $70 \%$. The fall in oil prices from June 2014, not only endangers Russian positions in world exports, but also brings a significant amount of uncertainty as to the issues of budget financing, and to the maintenance of financial stability of the Russian economy as a whole.

Table 1: GDP Countries for 2013-2015 (Billion Dollars USA)

\begin{tabular}{|r|l|r|r|r|}
\hline \multicolumn{1}{|c|}{ № Countries } & \multicolumn{2}{|c|}{2013} & 2014 & 2015 \\
\hline 1. & China & 16689 & 18228 & 19696 \\
\hline 2. & USA & 16692 & 17393 & 18037 \\
\hline 3. & India & 6739 & 7357 & 7998 \\
\hline 4. & Japan & 4683 & 4766 & 4843 \\
\hline 5. & Germany & 3639 & 3763 & 3860 \\
\hline 6. & Russia & 3734 & 3828 & 3725 \\
\hline 7. & Brazil & 3230 & 3292 & 3199 \\
\hline 8. & Indonesia & 2515 & 2689 & 2848 \\
\hline 9. & United Kingdom & 2492 & 2615 & 2702 \\
\hline 10. & France & 2542 & 2604 & 2666 \\
\hline
\end{tabular}

At the same time, Russia's share in global exports of high-tech products, according to the World Bank, remains extremely low $-0.36 \%$, behind the similar indicator to all of the BRICS countries (China $25.6 \%$; India $-0.63 \%$; Brazil - $0.45 \%$ ), besides RSA $(0.1 \%)$ (Explore. Create. Share: Development, 2015). At the beginning of this century, Russia has failed to achieve a tangible increase in the global share of the export of high technology products, which is primarily due to the low competitiveness of domestic goods and the unwillingness of producers to go to the foreign markets. The most promising markets for domestic enterprises, exporting high-tech products are the markets of developed countries, which, despite the competition, companies have the opportunity to make a profit at the expense of highercapacity markets of these countries. As for relationships between the developing countries and the establishment of the exchange of technology and knowledge-intensive goods, in this case, for the companies, in spite of the possible absence of competition, there are the same risks as when working on the Russian domestic market: low demand or no market for the product / service, infrastructure. In Russia, the low level of resource support for science, poor infrastructure to facilitate the development and implementation of R\&D (Research and Development) results are one of the most vulnerable aspects of modern development, hindering the strengthening of positions in the world markets, increase national competitiveness and global influence.

In the context of the risk of instability of the global economy, as well as a significant increase in competition, strengthening of positions in trade of high-tech products is possible if the implementation of complex scientific and technical measures, industry, trade policies in their relationship, including significant investments on an ongoing basis in the R\&D (Research and Development)sphere and creating conditions for the commercialization of R\&D (Research and Development) results (Khasbulatov, Lebedev, Migaleva \& Podbiralina, 2015).

Despite the social-economic and political changes in the rating of the World Bank's Doing Business in 2015 was promoted to Russia from 92nd to 62nd place that's why by changing the method of calculation, which was to take into account the reforms in Russia. In this key indicator of superior business climate as "registering property", Russia today occupies the 12th place, and found to comply 
with the criteria of transparency and exchange of tax information, along with the United States, Britain, Germany and Italy (World trade report, 2015).

At the beginning of the XXI century, there was an increase of autonomy of regions of Russia as the actors of the system of global economic relations. However, this process is developing very unevenly across the Russian Federation, on the areas around the edges.

It should be noted that the Russian Federation is characterized by uneven economic development of the regions, largely due to the factors of an objective nature (natural factors), which primarily include the historically developed infrastructure, industrial orientation of the region, climatic conditions, natural resource endowments, and others. In addition to objective factors, a significant impact on the socioeconomic development and has a regional economic policy and business environment. In 2014, an additional factor of influence became Western sanctions against individual economic actors, whole sectors of the Russian economy and financial infrastructure, as well as response.

According to a study on the social-economic development of the Russian Federation for 2015, prepared by the Russian rating agency RIA "Rating", still ahead of the rest of the metropolitan regions of Russia, and oil and gas field. Moscow, St. Petersburg and Khanty-Mansi Autonomous District on the majority of indicators are taken into account in the preparation of the rating is stable rank high, indicating strong fundamental assumptions of their socio-economic development. Moscow region, which can be attributed to the metropolitan area occupies the fourth position in the ranking, because of the high degree of integration in the framework of the Moscow metropolitan area.

The top ten includes two other leaders of the Urals Federal District regions, the Yamalo-Nenets Autonomous District (7th place) and the Tyumen region (9th place). Their economy is determined primarily by mining. At the top of the rankings and is a group of regions located around the largest Russian cities with a population between 1 and 1.5 million people. They are characterized by the development of industrial production, especially engineering. For example, Tatarstan and Samara region occupied by the 5th and 6th positions, and Sverdlovsk region is located on the 7 th place. The last line of the rating occupy the Republic of Altai,
Tyva and Ingushetia.

Thus, we see that in the Russian Federation there are indeed huge gaps in the level of social-economic development between the regions. This irregularity can be traced from the point of view of the territorial aspect: the five subjects of the Russian Federation (Republic of Sakha (Yakutia), the Krasnoyarsk Territory, the Khabarovsk Territory, the Irkutsk region, Yamalo-Nenets Autonomous District) occupy half of the territory of Russia, and - it is sparsely populated regions. The rest of the population is concentrated in 18 of the 85 countries of the regions. The level of concentration of the Russian economy as a whole, industrial production (manufacturing and especially the extractive industries), power generation, agricultural production at the regional level is even higher. For example, more than $50 \%$ of GDP is created in all 9 regions of Russia (for reference, only on the first three of them - Moscow, Khanty-Mansi Autonomous District and the Moscow region - accounting for a third of the Russian economy).

Review of the Russian Federation foreign trade development trends also shows significant differences in the participation of the Russian Federation in this process.

According to customs statistics for the period from 2013 to 2015 marked the fall of the key performance indicators (exports, imports and foreign trade) (Fig. 1).

Thus, the country's foreign trade turnover amounted to $\$ 844.2$ billion in 2013 , in 2014 there was a decrease this figure to US $\$ 793.968$ billion. In 2015, foreign trade turnover decreased significantly, to $\$$ 530.4 billion.

In the foreign economic strategy of the Russian Federation until 2020 indicated the need for more active involvement of Russian regions in foreign economic activities.

One of the most important factors affecting the integration of Russia into world economic relations, is the direct participation of individual regions of the Russian Federation in foreign trade activities, in particular, the distribution of import and export contacts in foreign countries and CIS countries. Given the fact that regions differ in terms of socioeconomic development, resource security, infrastructure, will be different, and their participation in foreign economic relations. 


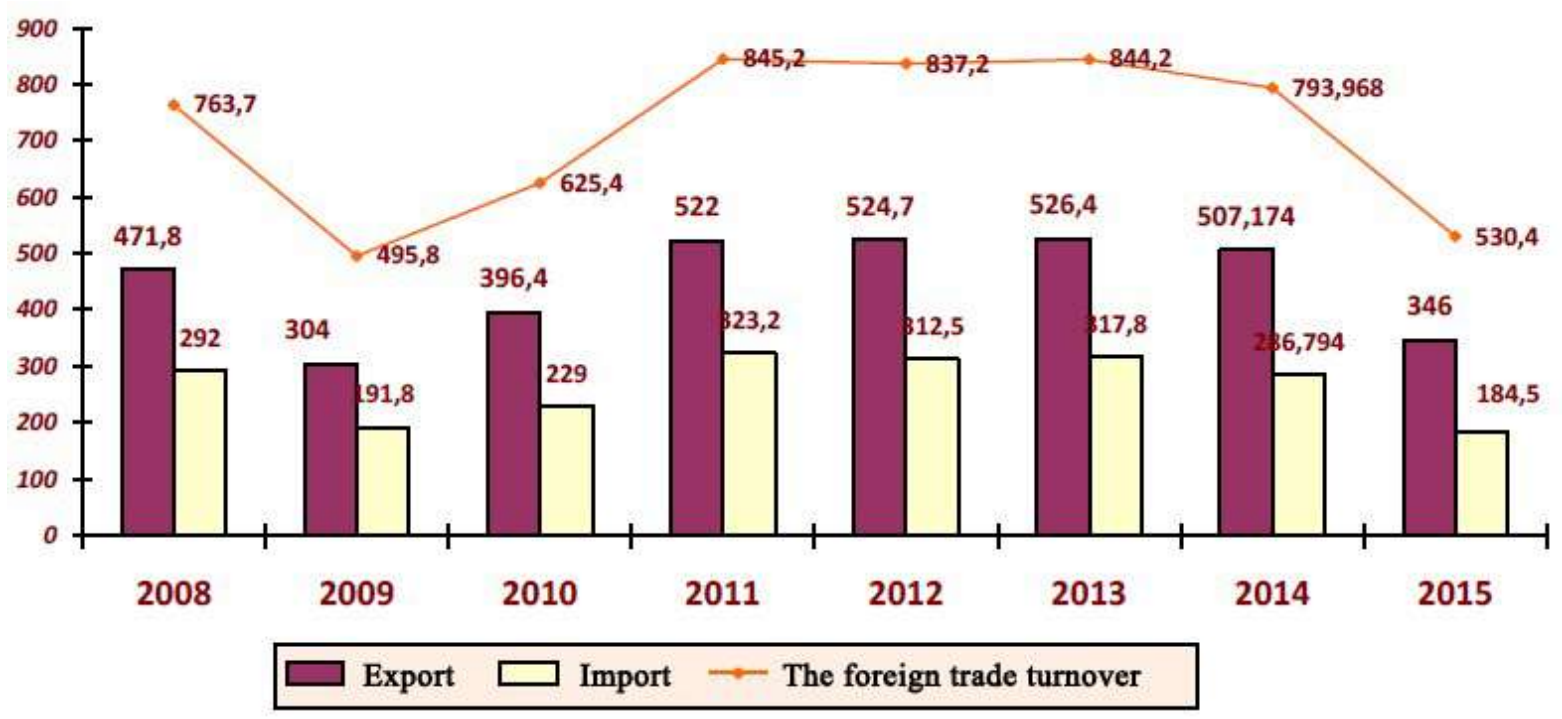

Fig. 1: The Foreign Trade Turnover of the Russian Federation in 2008-2015

According to the portal of foreign trade data, in 2015 the Central Federal District more actively involved in foreign trade activities. It accounts for the largest volume, both exports (US \$ 4.971 billion.), and imports of goods (US $\$ 80.3$ billion.). With regard to exports followed by Northwest (3.451 billion US dollars), Siberian (2,334 billion US dollars) and South (US \$ 2.021 billion) County.

Foreign trade activity in certain regions of Russia is developing very unevenly. The largest share of export falls on the Central (45.3\%), Volga (11.8\%), Ural $(11.1 \%)$ and North-West $(9.1 \%)$ Federal Districts. With regard to imports, leading positions naturally occupies the Central Federal District (57.5\%), Volga (5.4\%) and Ural (2.5\%), in turn, gives way to a given position of the North-West Federal District $(17,6 \%)$.

At the other extreme - Nenets and Chukotka Autonomous District, as well as the Jewish Autonomous Region. In these regions, these figures are in the range $0,0-0,7 \%$.

Thus, regions of Russia participated in the foreign economic activities of different and associated primarily with specificity resource potential, development of infrastructure and the level of socioeconomic development, as well as the country's overall development strategy. All these features also affect the structure of Russia's foreign trade.

Despite the adoption of a set of measures related to the support of innovative development, according to the Ministry of Economic Development, the share of export of Russian high-tech products in the GDP has fallen significantly over the past few years, reaching $11.8 \%$ at the end of $2015,70-80 \%$ of total exports constitute energy.

In accordance with the strategy of innovative development of the Russian Federation, one of the priorities of state policy is to encourage innovative development at the regional level.
In order to foster innovation in the territory of the Russian Federation carried out the creation of an innovative infrastructure, provides support for innovative entrepreneurship, undertaken a series of measures to stimulate the development of cooperation between science and business.

In some regions of the Central, Northwestern, Volga, Urals, Siberian and Far Eastern federal districts are located 25 innovative regional clusters, the list of which was approved by the instruction of the Prime Minister in August 2012. These clusters operate in the following areas of technological expertise: «Nuclear and radiation technologies», «manufacture of aircraft and spacecraft, ship building», «pharmaceuticals, biotechnology and medical industry», «new materials», «chemicals and petrochemicals», «information technologies and Electronics» (Piskulov, 2015).

At the federal level, using a range of measures designed to stimulate innovative development of regions.

The program to support small and medium-sized enterprises Economic Development of Russia regions provided federal funds for co-financing to support innovative companies as well as for specialized innovative programs containing measures for the creation and development of innovation infrastructure (cluster development centers, territorial, industrial, innovation and logistics clusters centers of collective access to high-tech equipment, prototyping and industrial design centers, technology competence centers, technology transfer centers).

According to the ranking of innovative development of the Russian Federation, in 2014 the leaders were Moscow, Tatarstan and St. Petersburg. The first group of the most progressive in terms of innovation, regions also includes: Nizhny Novgorod region, Kaluga region, the Chuvash Republic, Sverdlovsk region, Tomsk region, Moscow region, Ulyanovsk 
region, Perm, Novosibirsk region. Lower line rating occupies the Republic of Ingushetia, Kalmykia, Chechnya.

\section{Results and Discussion}

According to the authors, the country remains vulnerable to the situation with the unbalanced structure of the economy in all its dimensions: firstly, a clear predominance of fuel and raw materials sectors to the detriment of mechanical engineering and machine tool; secondly, the weak development of modern high-tech industries in most engineering structure; thirdly, the weak development of small and medium business sector, which is characterized by high competitiveness; fourthly, it is unacceptable disregard not just to agriculture and livestock, and to the village as a whole issues. Recall that the Chinese breakthrough began with the villages: in the 19801993 years, there was a gigantic revolution, China has not only become to provide their own food needs, but also to increase agricultural exports annually.

Development of the conflict that engulfed Russia economic relations with the countries of the world is in contradiction with the fundamental principles of the WTO (the World Trade Organization), the World Bank, and the IMF, which makes it difficult, but should not exclude the participation of the Russian Federation. On the contrary, the activities of the institutions of international economic cooperation can be an important tool in the way of normalization of the situation in the trade and economic relations.

Based on research, the authors believe that the market economy of our country should gradually withdraw from the sale, depending on the energy, you need to implement in practice, declared in 2005 the political course of the formation of an innovative economy in Russia, because innovative economy - a step towards building a new information society, which can entirely new ways to solve the problems of employment and wealth distribution issues that create social tensions today worldwide. This course must allow the use of once all the unique advantages of our country, not only the richness of its mineral resources, but also the unique natural conditions, allowing to have a developed agriculture, founded in the years of Soviet industrial and scientific potential to be restored and used actively for the benefit of the national economy, and as a result - for the benefit of the Russian people. All this is very difficult to do if, for participation in the geopolitical confrontation is necessary to legislatively restrict foreign trade, sell energy at below market prices in order to maintain political ties with certain countries (Khasbulatov, Lebedev, Migaleva \& Podbiralina, 2015).

\section{Summary and Conclusion}

In summary, it follows to say that it is necessary to work hard to find new ways of persuasion countries: the necessity for non-economic confrontation with our country, and try to agree on the principles of mutual trust and incorporate common business structures, the proportionality of regional and global interests, the concentration of joint efforts in the field of advanced technologies and the creation of a single market for goods and services.

\section{References}

[1] Amirova, D.R., Gudkova, V.S. (2014). Sovremennye osobennosti vneshneehkonomicheskoj deyatelnosti Rossijskoj Federacii. Gumanitarnye nauchnye issledovaniya, 12-2 (40), 86-92 (In Russian).

[2] Explore. Create. Share: Development Data (2015), http://databank.worldbank.org.

[3] Khasbulatov, R.I., Lebedev, I.F., Migaleva, T.E., Podbiralina, G.V. (2015). The Russian Federation in the world economy the position and the new tasks. International economics, 2, 4-16 (In Russian).

[4] Labudin, A.V., Rafikov, S.A. (2012). Tendencii differenciacii I integracii rossijskogo ehkonomicheskogo prostranstva upravlencheskoe konsultirovanie, 2 (46), 107-114 (In Russian).

[5] Marcel P.Timmer, Abdul Azeez Erumban, Bart Los, Robert Stehrer\&Gaaitzen J.de Vries (2014). Slicing Up Global Value Chains. The Journal of Economic Perspectives, 28 (2), 99-118(20).

[6]Nicholas Bloom, Mirko Draca\&John Van Reenen (2015). Trade Induced Technical Change? The Impact of Chinese Imports on Innovation, IT and Productivity. The review of economic studies, 83 (1), 87-117.

[7] Perova A.E. (2016). Features of development of Russia's foreign trade in the long term. International Research Journal, 10-1 (52), 62-68.

[8] Piskulov, Y.U. (2015). V Rossiya-zapad obratnaya storona konflikta mezhdunarodnaya ehkonomika, 1, 4-8 (In Russian).

[9] Scott R. Baker, Nicholas Bloom \&Steven J. Davis (2015). Measuring Economic Policy Uncertainty. Journal of Economics, 2016, http: //qje.oxfordjournals.org.

[10] Selyukov, M. V., Shalygina N. P., Petrushko E. N., Moskalenko O. A., Ospishchev P. I., Lesovaya S.L. (2016). Evolution of customs authorities management of the Russian Federation, considering transition to an innovative principle of economic development. Journal of Fundamental and Applied Sciences, 8(2S), 1450-1457.

[11] Shchukov, V.N. (2016). Potencial rossijskoj ehkonomiki problem innovacionnogo razvitiya. Sovremennye naukoemkie tekhnologii. Regionalnoe prilozhenie, 3, 164-169 (In Russian).

[12] Siri Terjesen, J. Hessels \& Dan Li (2013). Comparative International Entrepreneurship: A Review and Research Agenda. Journal of Management, X, 1-46.

[13] World trade report (2015), https://www.wto.org/english/res_e/publications_e/wtr 15_e.htm. 